\title{
Застосування вакуумної терапії ран в лікуванні інфекційних ускладнень з боку післяопераціӥних ран
}

\begin{abstract}
Мета роботи: поліпшити результати лікування хворих з інфекційними ускладненнями з боку післяопераційних ран. Матеріали и методи. Впродовж 2014 - 2019 рр. у відділенні гнійної хірургії Київської міської лікарні № 3 (база кафедри загальної хірургії № 2 Національного медичного університету імені О. О. Богомольця) проходили лікування 47 хворих з інфекційними ускладненнями з боку післяопераційних ран. Вік пацієнтів склав (45,7 \pm 12$)$ року, серед них - 27 (57,4 \%) чоловіків та 20 (42,6 \%) жінок. У дослідній групі лікування здійснювали з використанням мобільної помпи для вакуумної терапії ран NPWT KCI ActiVAC $300 \mathrm{ml}$. У групі порівняння використовували накладання традиційних марлевих пов'язок з розчинами антисептиків. Усім хворим в обох групах проводили антибактеріальну терапію, лікування супутньої патології.

Результати досліджень та їх обговорення. Згідно з результатами бактеріологічного дослідження ранового вмісту у хворих дослідної групи на третю добу мікробне число знизилося до $10^{5}-10^{6}$, у мазках-відбитках некротичний тип цитограм змінився на дегенеративно-запальний тип у 19 (73,0\%) хворих і в 7 (27,0\%) хворих на запально-регенераторний тип, тоді як в групі порівняння показники мікробних чисел залишалися на попередньому рівні $10^{8}-10^{9}$ та у $15(71,4 \%)$ ще зберігався некротичний тип цитограм та лише у 6 (28,6\%) хворих спостерігався дегенеративно-запальний тип цитограм. На 10 добу в дослідній групі у 24 (92,3 \%) хворих мав місце регенераторний тип цитограм, у 2 (7,7\%) хворих - запально-регенераторний тип. В порівняльній групі у 15 (71,5\%) мав місце дегенеративно-запальний тип, в 4 (19,0 \%) - запально-регенераторний тип цитограм, а в 2 (9,5\%) хворих - некротичний тип.

Використання вакуумної терапії ран при інфекційних ускладненнях післяопераційних ран значно покращує результати лікування і скорочує терміни реабілітації хворих.
\end{abstract}

Ключові слова: вакуумна терапія ран; інфекційні ускладнення; післяопераційна рана.

Постановка проблеми і аналіз останніх досліджень та публікацій. Хірургія як одна із базових наук медицини тісно пов'язана з такими поняттями, як “рана” та “рановий процес”. Проблема лікування гострих та хронічних гнійних ран є надзвичайно актуальною й на сьогодні $[1,2]$. Згідно 3 даними Всесвітньої організації охорони здоров'я, гнійні захворювання зустрічаються в третини хірургічних хворих [3, 4]. Основні складнощі при лікуванні хворих із гнійними захворюваннями в наш час пов'язані: з появою антибіотикорезистентних штамів мікроорганізмів, які викликають гнійно-септичні ускладнення, з розширенням видової належності гноєутворювальної мікрофлори. Окрім того, утворення мікробних біоплівок на поверхні ран створює труднощі при загальному та місцевому застосуванні антибактеріальних препаратів $[5,6]$. Частота гнійно-запальних ускладнень після герніопластик досягає 28,3 \%, після резекції шлунку - 4-28,4 \%, холецистектомій - 3,9-32 \%, апендектомій - 40,4 \%, хірургічному лікуванні гострих панкреатитів - 40-70 \%, операцій на товстій кишці - 68 \% [1, 5, 6]. Найбільш тяжким ускладненнями в абдомінальній хірургії є перитоніт, частота розвитку якого коливається від 3 до 70 \%, 3 летальністю від 16 до 80 \% [7, 8]. Мікробна контамінація операційної рани $є$ неминучою навіть при дотриманні правил асептики й антисептики, наприкінці операції в 80-90 \% випадків рани вже заражені різною мікрофлорою, найчастіше - стафілококами, при цьому, гнійні ускладнення розвиваються у 2 - 30 \% післяопераційних пацієнтів. Інфекція розвивається при порушенні рівноваги між мікроорганізмами, які забруднюють рану, i стану захисних механізмів макроорганізму. Важлива роль належить функціональному стану пошкоджених в процесі операції або в процесі хвороби тканин $[7,9]$. Сучасні методи лікування (антибіотикотерапія, дренування ран та порожнин) не завжди дають змогу успішно вирішити дану проблему, що спонукає до пошуку та розробки нових, зокрема специфічних засобів лікування [10].

Мета роботи: поліпшити результати лікування хворих із інфекційними ускладненнями з боку післяопераційних ран.

Матеріали і методи. Протягом 2014-2019 рр. у клініці гнійної хірургії Київської міської лікарні № 3 (база кафедри загальної хірургії № 2 Національного медичного університету імені О. О. Богомольця) отримали лікування 47 хворих з інфекційними ускладненнями з боку післяопераційних ран. Вік пацієнтів склав $(45,7 \pm 12)$ року. Чоловіків було 27 (57,4 \%), жінок 20 (42,6 \%). 
На початку даної роботи ми обрали дослідну та порівняльну групи, в які увійшли хворі з нагноєнням ран після хірургічного лікування. Дослідну групу склали 26 (55,3 \%) хворих, порівняльну - 21 (44,7 \%). В рутинний план обстеження включали: загальний аналіз сечі, загальний аналіз крові та аналіз крові на цукор, біохімічний аналіз крові з визначенням білірубіну, загального білка, креатиніну, сечовини. 3 інструментальних методів виконували рентгенографію органів грудної порожнини, електрокардіограму, ультразвукове дослідження (УЗД) органів черевної порожнини та м'яких тканин у ділянці ураження.

Контроль за перебігом ранового процесу здійснювали за клінічним даними (зменшення набряку, болю, нормалізація температури тіла, відсутність гіперемії шкіри), оцінкою лейкоцитарного індек- су інтоксикації (ЛІІ), який визначали за формулою Я. Я. Кальф-Каліфа в модифікації В. К. Островського [11]: ЛІІ = (плазматичні клітини + мієлоцити + юні + паличкоядерні + сегментоядерні нейтрофіли) / (лімфоцити + моноцити + еозинофіли + базофіли), С-реактивного білка, гематологічного показника інтоксикації (ГПІ) за В. С. Васільєвим. Дослідження вогнищ гнійної інфекції здійснювали за допомогою бактеріологічного методу. Чутливість до антибіотиків оцінювали диско-дифузним методом Кірбі-Бауера. Цитологічне дослідження ранового ексудату проводили методом мазків-відбитків за стандартною методикою (Покровська М. П., Макаров М. С. в модифікації Штейнберга А. Д.). В таблиці 1 наведена динаміка показників рівня ендогенної інтоксикації в порівняльній та дослідній групах залежно від проведеного лікування.

Таблиця 1. Динаміка показників рівня ендогенної інтоксикації

\begin{tabular}{|c|c|c|c|c|c|}
\hline Показники & Норма & $\begin{array}{c}\text { Порівняльна група } \\
\text { (n-26) }\end{array}$ & $\begin{array}{c}\text { Дослідна група } \\
\text { (n-21) }\end{array}$ & $\begin{array}{l}\text { Протягом } \\
\text { лікування }\end{array}$ & До лікування \\
\hline \multirow{3}{*}{$\begin{array}{l}\text { Лейкоцити } \\
\left(\times 10^{9} / л\right)\end{array}$} & \multirow[t]{3}{*}{$4-8,8$} & $10,3 \pm 0,9$ & $8,8 \pm 0,8$ & 3 доба & \multirow[t]{3}{*}{$13,8 \pm 0,57$} \\
\hline & & $9,4 \pm 0,5$ & $7,4 \pm 0,9$ & 7 доба & \\
\hline & & $8,5 \pm 0,9$ & $7,1 \pm 0,8$ & 10 доба & \\
\hline \multirow{3}{*}{$\begin{array}{l}\text { ЛІІ, } \\
\text { (умов. од.) }\end{array}$} & \multirow[t]{3}{*}{$1,0 \pm 0,6$} & $3,77 \pm 0,37$ & $2,83 \pm 0,31$ & 3 доба & \multirow[t]{3}{*}{$4,77 \pm 0,28$} \\
\hline & & $2,87 \pm 0,81$ & $1,91 \pm 0,34$ & 7 доба & \\
\hline & & $1,93 \pm 0,47$ & $1,0 \pm 0,44$ & 10 доба & \\
\hline \multirow{3}{*}{$\begin{array}{l}\text { ГПІ } \\
\text { (умов. од.) }\end{array}$} & \multirow[t]{3}{*}{$0,69 \pm 0,09$} & $1,65 \pm 0,31$ & $0,91 \pm 0,11$ & 3 доба & \multirow[t]{3}{*}{$2,28 \pm 0,13$} \\
\hline & & $1,22 \pm 0,42$ & $0,71 \pm 0,11$ & 7 доба & \\
\hline & & $0,72 \pm 0,13$ & $0,66 \pm 0,03$ & 10 доба & \\
\hline \multirow{4}{*}{$\begin{array}{l}\text { С-реактивний } \\
\text { білок (мг/л) }\end{array}$} & \multirow[t]{4}{*}{$0-10$} & $30,7 \pm 1,6$ & $19,3 \pm 1,4$ & 3 доба & \multirow[t]{4}{*}{$41,1 \pm 2,1$} \\
\hline & & $17,8 \pm 1,7$ & $12,5 \pm 1,3$ & 6 доба & \\
\hline & & $11,6 \pm 1,5$ & $9,2 \pm 1,1$ & 9 доба & \\
\hline & & & & 12 доба & \\
\hline
\end{tabular}

Хворі обох груп розподілені за типом виконаних операційних втручань (табл. 2).

Хворим в обох групах широко розкривали рани шляхом зняття швів, видаляли рановий вміст разом $з$ некротично зміненою жировою клітковиною, здійснювали забір матеріалу для бактеріологічного дослідження, з ранової поверхні брали мазки-відбитки. Після цього ранову поверхню промивали розчином Октенісепту (Schulke \& Mayr GmbH). Хворим дослідної групи накладали мобільну помпу для вакуумної терапії ран. Ми ви- користовували апарат NPWT KCI ActiVAC $300 \mathrm{ml}$ протягом 3-х діб (72 год), який працював в постійному режимі з розрідженням 120 мм рт. ст. Після цього проводили демонтаж системи та візуально оцінювали ранову поверхню та робили мазок-відбиток. На одну добу накладали марлеву пов’язку з октенісептом, після чого налаштовували повторну мобільну помпу для вакуумної терапії на чотири доби. У хворих порівняльної групи здійснювали перев'язки з використанням розчинів антисептиків (декасан, октенісепт, пронтосан) в поєднанні 3 
Таблиця 2. Розподіл хворих за типом операційних втручань

\begin{tabular}{||l|c|c||}
\hline \multicolumn{1}{|c|}{ Вид операційного втручання } & $\begin{array}{c}\text { Дослідна група } \\
(\mathrm{n}-26)\end{array}$ & $\begin{array}{c}\text { Порівняльна група } \\
(\mathrm{n}-21)\end{array}$ \\
\hline Лапаротомія з приводу кишкової непрохідності & 8 (30,7 \%) & 7 (33,3 \%) \\
\hline Лапаротомія з приводу тромбозу мезентеріальних судин & $10(38,5 \%)$ & $9(42,8 \%)$ \\
\hline Герніотомія з імплантацією сітки та абдомінопластикою & $4(15,4 \%)$ & $2(9,5 \%)$ \\
\hline Лапаротомія з приводу перфорації виразки ДПК & $4(15,4 \%)$ & $3(14,4 \%)$ \\
\hline Всього & $26(100 \%)$ & $21(100 \%)$ \\
\hline \hline
\end{tabular}

борною кислотою або ферментами один раз на добу. Усім хворим в обох групах проводилася антибактеріальна терапія згідно з експрес-методом на чутливість до антибіотика, антиоксидантна терапія, лікування супутньої патології.

Результати досліджень та їх обговорення. Згідно з отриманими результатами нашого дослідження в посіві ранового вмісту були виявлені: Staphylococcus aureus 37,7 \%, Staphylococcus epidermidis 26,5 \%, Enterococcus faecalis 10,5\%, Escherichia coli; 9,7 \%, Proteus vulgaris 7,7 \%, Klebsiella pneumonie 5,8 \%, а також грампозитивні аеробні та факультативно анаеробні збудники 2,1 \% (рис. 1).

В обох групах ЛЛІ в перший день коливався в межах 4,77 \pm 0,28, що свідчило про наявність ін- токсикаційного синдрому на тлі гнійно-некротичного процесу, в мазках-відбитках мав місце некротичний тип цитограм, який характеризується повною клітинною ареактивністю. В дослідній групі на третю добу після демонтажу мобільної помпи в мазках-відбитках мав місце дегенеративнозапальний тип цитограм у 19 (73,0 \%) хворих і в 7 (27,0 \%) хворих запально-регенераторний тип. В порівняльній групі у 15 (71,4 \%) зберігався некротичний тип цитограм та у 6 (28,6 \%) хворих дегенеративно-запальний тип цитограм. На 10 добу в дослідній групі у 24 (92,3 \%) хворих мав місце регенераторний тип цитограм, у 2 (7,7 \%) хворих запально-регенераторний тип. В порівняльній групі у 15 (71,5 \%) мав місце дегенеративно-запальний тип, в 4 (19,0 \%) запально-регенераторний тип цитограм, а в 2 (9,5 \%) хворих некротичний тип.

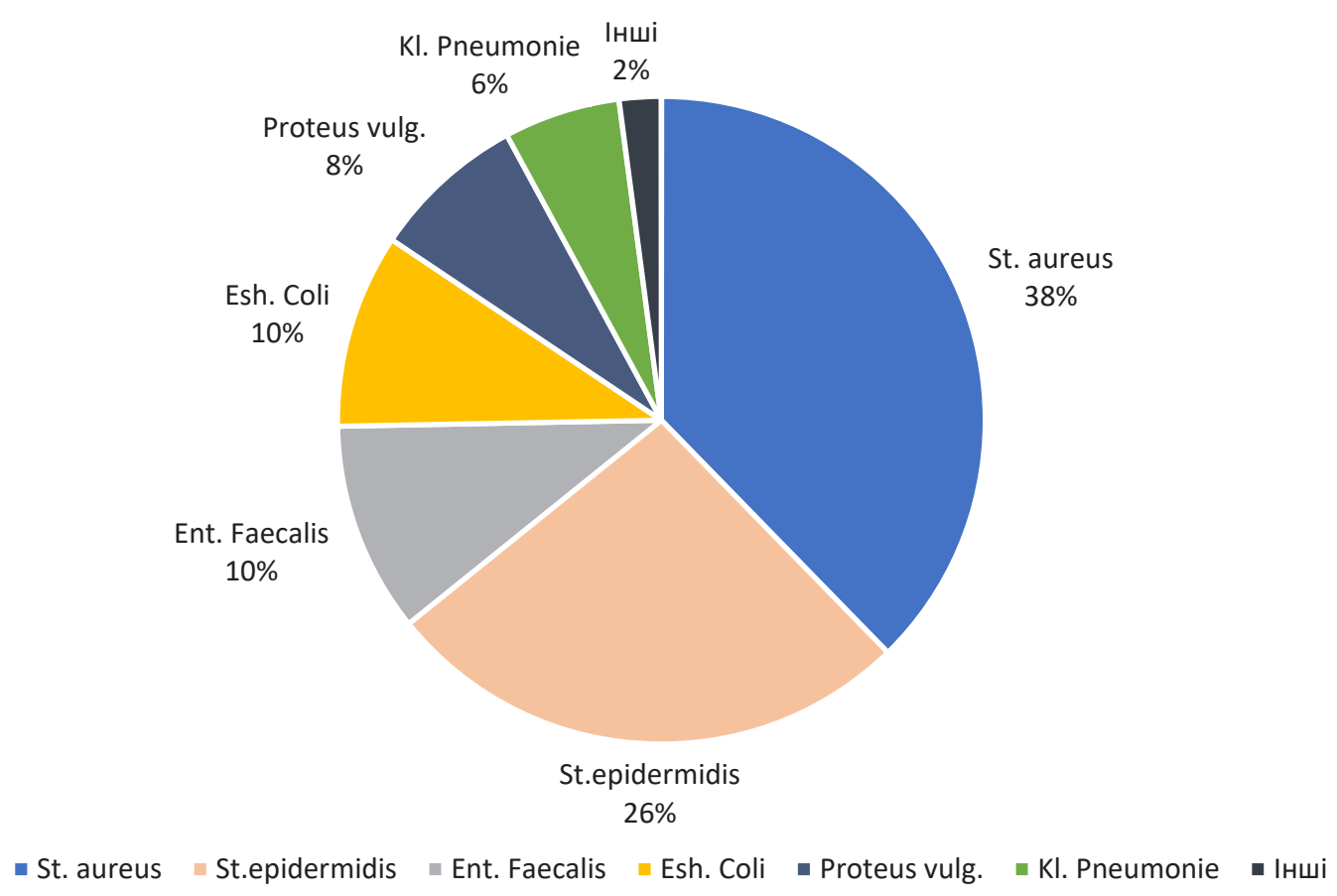

Рис. 1. Результати бактеріологічного дослідження ран. 
Згідно $з$ результатами бактеріологічного дослідження ранового вмісту у хворих дослідної групи з третьої доби мікробне число знизилося до $10^{5}-10^{6}$, в порівняльній групі ці показника залишалися на попередньому рівні $10^{8}-10^{9}$.

Після досягнення повного купірування запального процесу та очищення рани закриття ранового дефекту виконували шляхом накладання вторинних швів.

У 2 хворих порівняльної групи, в яких була виконана герніотомія з імплантацією сітки внаслідок прогресування процесу, видалили сітку. Нижче наводимо клінічний випадок, коли завдяки ранньому застосуванню системи від'ємного тиску вдалось зберегти сітчастий алотрансплантат, не зважаючи на тотальне нагноєння післяопераційної рани.

Клінічний випадок. Пацієнтка Н. В., 1964 р. н. госпіталізована в хірургічне відділення для планового хірургічного втручання 3 діагнозом: “Абдоміноптоз. Деформація передньої черевної стінки. Післяопераційна вентральна грижа. ЖКХ. Хронічний калькульозний холецистит. Варикозна хвороба обох нижніх кінцівок ХВН ст. I (CEAР)". 05.02.2020 р. проведено хірургічне лікування абдомінопластику. Герніоалопластику післяопераційної вентральної грижі із встановленням сітчатого трансплантату за методикою sublay. Післяопераційний перебіг ускладнений локальним нагноєнням п/о рани. Тричі було встановлено систему вакуумного дренування післяопераційної рани апаратом NPWT KCI ActiVAC в постійному режимі роботи з розрідженням 120 мм рт. ст. На 30-ту добу у задовільному стані виписана для амбулаторного лікування (рис. 2-8).

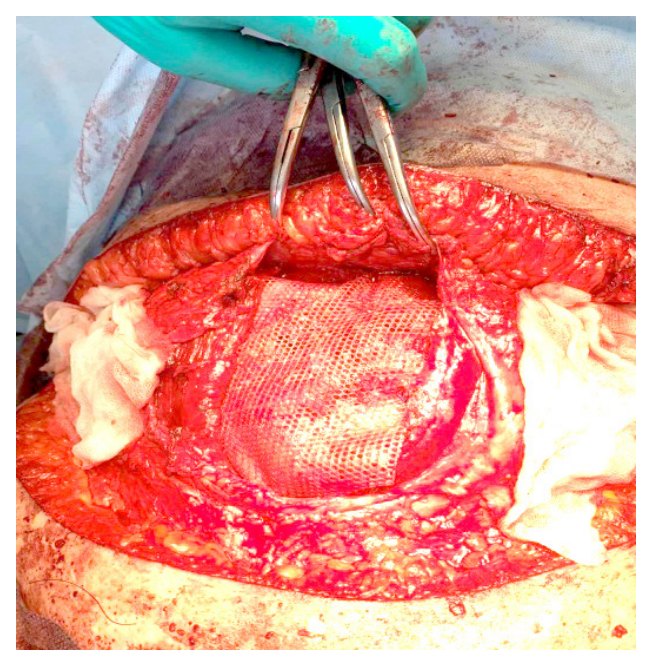

Рис. 2. Пацієнтка Н. В., 1964 р. н. Інтраопераційне фото. Абдомінопластика, герніоалопластика п/о вентральної грижі із встановленням сітчастого трансплантату за методикою sublay.

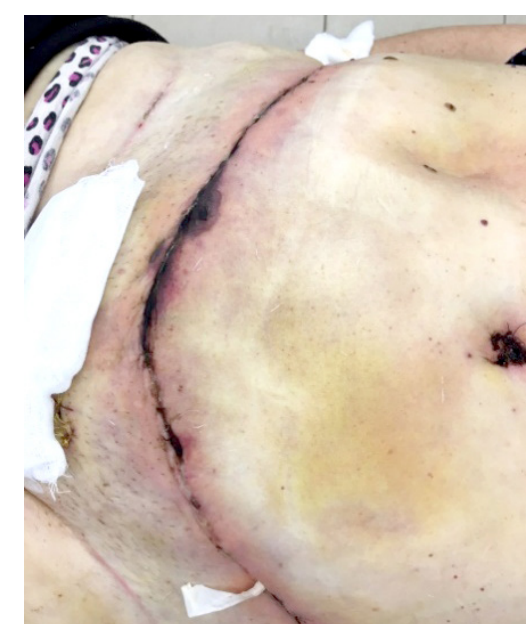

Рис. 3. Пацієнтка Н. В., 1964 р. н. 6-та п/о доба. Післяопераційний перебіг, ускладнений локальним нагноєнням п/о рани. Встановлено гумові дренажі.

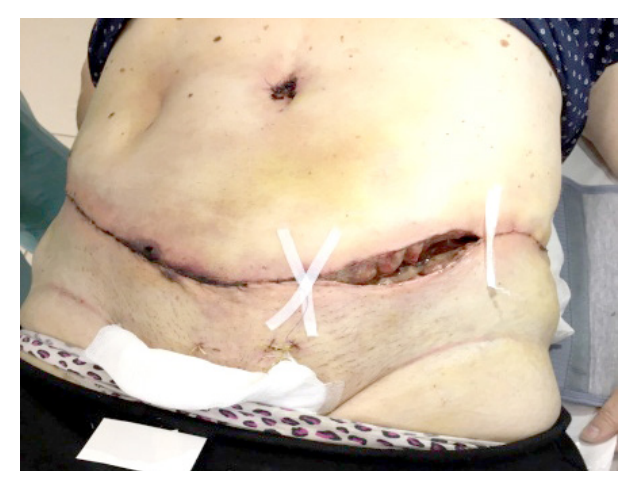

Рис. 4. Пацієнтка Н. В., 1964 р. н. 7-ма п/о доба. Незважаючи на дренування рани гумовими випускниками у пацієнтки зберігалась температура тіла $-38,5^{\circ} \mathrm{C}$, в ділянці п/о рани локальна гіпертермія на 3 см нижче від пупка справа. За результатом бактеріологічного дослідження ранового вмісту отримано Staphylococcus aureus $10^{5} \mathrm{~K} / \mathrm{Mл}$.

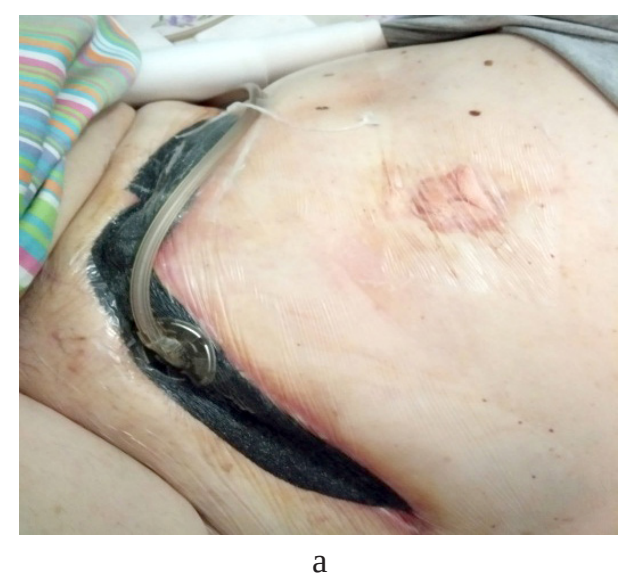

Рис. 5. Пацієнтка Н. В., 1964 р. н. 14-та п/о доба. На ранову поверхню передньої черевної стінки накладено апарат NPWT KCI ActiVAC в постійному режимі роботи з розрідженням 120 мм рт. ст. на 72 години. 


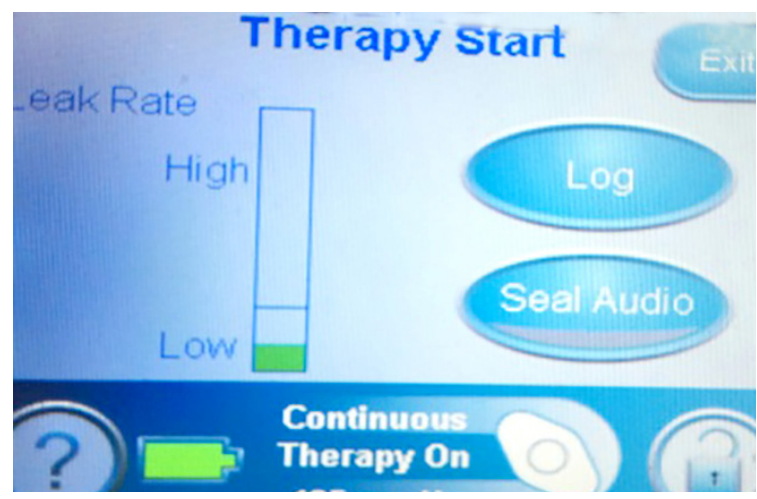

6

Рис. 5 (продовження). Пацієнтка Н. В., 1964 р. н. 14-та п/о доба. На ранову поверхню передньої черевної стінки накладено апарат NPWT KCI ActiVAC в постійному режимі роботи з розрідженням 120 мм рт. ст. на 72 години.
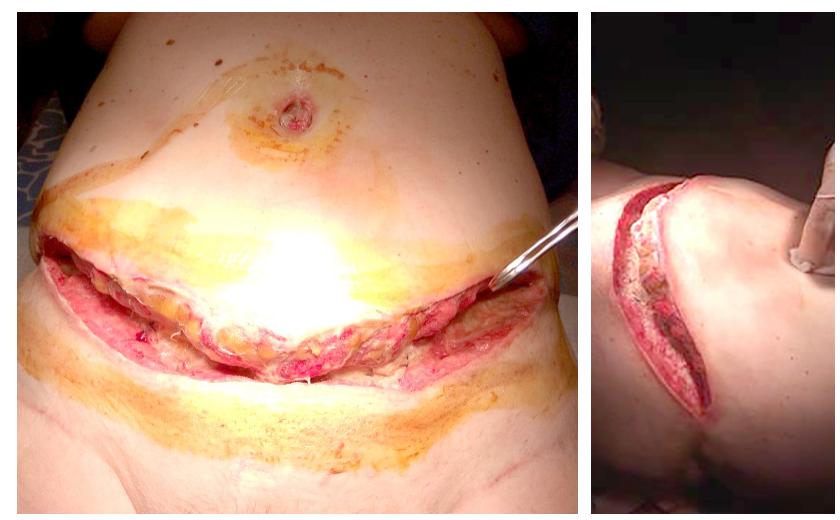

Рис. 6. Пацієнтка Н. В., 1964 р. н. 17-та п/о доба. П/о рана після накладання апарату NPWT KCI ActiVAC в постійному режимі роботи з розрідженням 120 мм рт. ст. протягом 96 годин.

Висновки. Використання вакуумної терапії при обширних нагноєннях післяопераційних ран значно пришвидшує купірування гнійного процесу та підготовку рани для накладання вторинних швів. Крім того, при використанні VAC систем

\section{СПИСОК ЛІТЕРАТУРИ}

1. Блатун Л. А. Местное медикаментозное лечение ран / Л. А. Блатун // Хирургия. - 2011. - № 4. - С. 51-59.

2. Светухин А. М. Современное состояние проблемы использования антибактериальной терапии в комплексном хирургическом лечении больных с синдромом диабетической стопы / А. М. Светухин, М. В. Прокудина // Рус. мед. журн. - 1997. T. 5, № 24. - C. 1617-1620.

3. The use of vacuum-assisted closure therapy for the treatment of lower-extremity wounds with exposed bone / A. J. Defranzo, L. C. Argenta, M. W. Marks [et al.] // Plast. Reconstruct. Surg. 2001. - Vol. 108, No. 5. - P. 1184-1191.

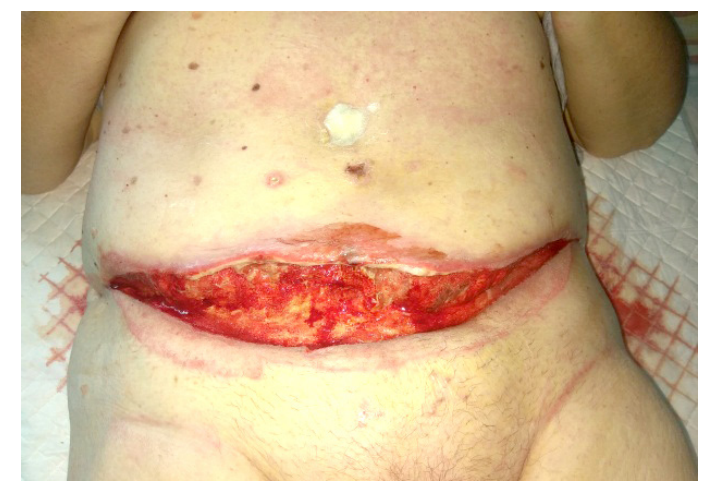

Рис. 7. Пацієнтка Н. В., 1964 р. н. 30-та п/о доба. Після наступного накладання апарата NPWT KCI ActiVAC в постійному режимі роботи з розрідженням 120 мм рт. ст. 72 годин.

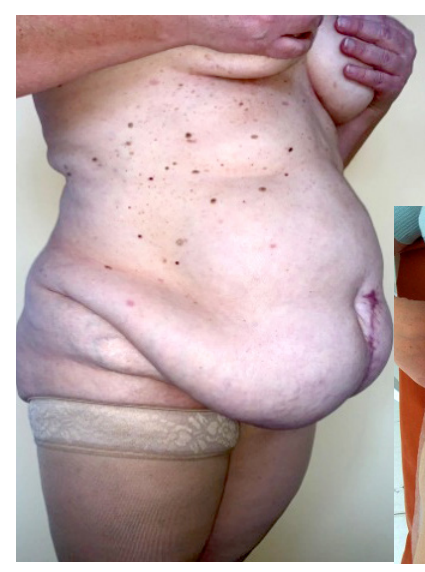

a

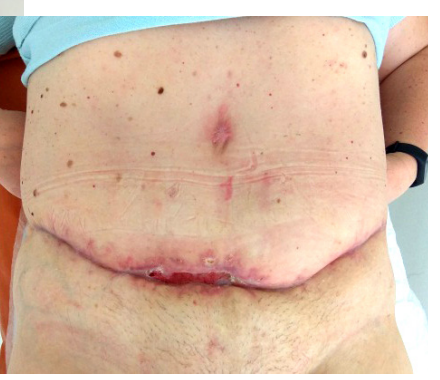

б
Рис. 8. Пацієнтка Н. В., 1964 р. н. Фото спереду та результат після хірургічного лікування на 60-ту п/о добу. Загоєння гранулюючої рани передньої черевної стінки.

можна запобігти відторгненню та інфікуванню сітчастих трансплантатів при різних видах герніоалопластики. Перевагою також є зменшення часу перебування хворого в стаціонарі та скорочення термінів реабілітації.

4. Costs and duration of care for lower extremity ulcers in patients with diabetes / S. E. Holzer, A. Camerota, L. Martens [et al.] // Clin. Ther. - 1998. -- Vol.20, №1. - P.169-181.

5. Антибиотикорезистентность биопленочных бактерий / И. В. Чеботарь, А. Н. Маянский, Е. Д. Кончакова [и др.] // Клинич. микробиол. и антимикроб. химиотер. - 2012. - Т. 14, № 1. - C. 51-58.

6. Osteomyelitis and the role of biofilms in chronic infection / R. A. Brady, Jason H. Calhoun, J. William Costerton [et al.] // Med. Microbiol. Immunol. - 2008. - Vol. 52. - P. 13-22.

7. Кубышкин В. А. Антибиотикопрофилактика инфекции обла- 
сти хирургического вмешательства в плановой абдоминальной хирургии / В. А. Кубышкин, Е. П. Хлебников // РМЖ. Урология. Хирургия. - 2003. - № 24, Т. 11. - С. 43-48.

8. Изучение особенностей микрофлоры раневого отделяемого при лапароскопических и лапаротомных вмешательствах на желчных путях / Ю. А. Ягнюк, А. М. Марющенко, А. В. Бакуменко [и др.] // Annals of Mechnicov Institute. - 2007. - № 2. - C. 22-24.

9. Липатов В. А. Патогенез раневого процесса и подходы к лечению гнойных ран / В. А. Липатов // Хирургия. - 2005. № 10. - С. 27-30.

\section{REFERENCES}

1. Blatun, L. (2011). Mestnoe medikamentoznoe lechenie ran [Local drug treatment of wounds]. Khirurgiya. Zhurnal N.I. PirogovaSurgery. Journal by N.I. Pirogov, 4, 51-59 [in Russian].

2. Svetuhin, A., \& Proskudina, M. (1997). Sovremennoe sostoyanie problemy ispolzovaniya antibakterialnoy terapii $\mathrm{v}$ kompleksnom khirurgicheskom lechenii bolnykh s sindromom diabeticheskoy stopy [Current state of the problem of using antibacterial therapy in the complex surgical treatment of patients with diabetic foot syndrome]. Russ. Med. Zhurnal - Russian Medical Journal, 5 (24), 1617-1620 [in Russian].

3. Defranzo, A. (2001). The use of vacuum-assisted closure therapy for the treatment of lower-extremity wounds with exposed bone. Plast. Reconstruct. Surg., 108 (5), 1184-1191.

4. Holzer, S.E., Camerota, A., \& Martens, L. (1998). Costs and duration of care for lower extremity ulcers in patients with diabetes. Clin. Ther., 20 (1), 169-181.

5. Chebotar, I. (2012). Antibiotikorezistentnost bioplenochnych bakteriy [Antibiotic resistance of biofilm bacteria]. Klinicheskaya Mikrobiologiya i antimikrobnaya khimioterapiya - Clinic. Microbiology and Antimicrobial. Chemotherapy, 14 (1), 51-58 [in Russian].

6. Brady, R. (2008). Osteomyelitis and the role of biofilms in chronic infection. Med. Microbiol. Immunol., 52, 13-22.

7. Kubyshkin, V., \& Chlebnikov, E. (2003). Antibiotikoprofilaktika infektsii oblasti khirurgicheskogo vmeshatelstva v planovoy abdominalnoy khirurgii [Antibiotic prophylaxis of infection in the area of surgical intervention in elective abdominal sur-
10. Вакуумная терапия ран с использованием генератоpa "WaterLily" : учеб.-метод. пособие / А. Ч. Часнойть, В. Н. Подгайский, Я. Я. Кошельков [и др.]. - Минск : БелМАПО, 2014. - 59 с.

11. Лейкоцитарный индекс интоксикации и некоторые показатели крови при оценке тяжести течения и определении прогноза воспалительных, гнойных и гнойно-деструктивных заболеваний разных локализаций / В. К. Островский, А. В. Мащенко, Д. В. Янголенко [и др.] // Анестезиология и реаниматология. - 2005. - № 6. - С. 25-29.

gery]. RMJ. Urologia. Hirurgiya - RMJ. Urology. Surgery, 24 (11), 43-48 [in Russian].

8. Yagniuk, Yu.A. Maryushchenko, A.M., Bakumenko, A.V., Volkov, A.A., \& Pyatakov, A.V. (2007). Izuchenie osobennostey mikroflory ranevogo otdelyaemogo pri laparoskopicheskikh i laparatomnykh vmeshatelstvakh na zelchnych putyakh [Study of the characteristics of the microflora of the wound discharge during laparoscopic and laparotomy interventions on the biliary tract]. Annals of Mechnicov Institute (2), 22-24 [in Russian].

9. Lipatov, V. (2005). Patogenez ranevogo protsesa i podkhody $\mathrm{k}$ lecheniyu gnoynykh ran [Pathogenesis of the wound process and approaches to the treatment of purulent wounds]. KhirurgiaSurgery, 9 (10), 27-30 [in Russian].

10. Chasnoyt, A.Ch., Podgaysky, V.N., \& Koshelkov, Y.Ya. (2014). Vakuumnaya terapiya ran s ispolzovaniem generatora "WaterLily" [Vacuum wound therapy using the "WaterLily" generator]. Minsk: BelMAPO [in Russian].

11. Ostrovsky, V.K., Mashchenko, A.V., \& Yangolenko, D.V. (2005). Leykotsytarnyy indeks intoksikatsii i nekotorye pokazateli krovi pri otsenke tyazhesti techeniya i opredeleniya prognoza vospalitelnykh, gnoynykh i gnoyno-destruktivnykh zabolevaniy raznykh lokalizatsiy [The leukocyte intoxication index and some blood indices in assessing the severity of the course and determining the prognosis of inflammatory, purulent and purulent-destructive diseases of different localizations]. Anesteziologia i reanimatologia - Anesthesiology and Intensive Care, (6), 25-29 [in Russian].

\section{THE IMPLEMENTATION NEGATIVE PRESSURE WOUND THERAPY FOR THE TREATMENT OF INFECTIOUS COMPLICATIONS OF POSTOPERATIVE WOUNDS}

The aim of the work: to improve the results of treatment of patients with infectious complications of postoperative wounds. Materials and Methods. During 2014-2019 in the Surgery Department of Kyiv City Hospital No. 3 (clinical base of the Department of General Surgery No. 2 of O. Bohomolets National Medical University) 47 patients were treated with infectious complications of

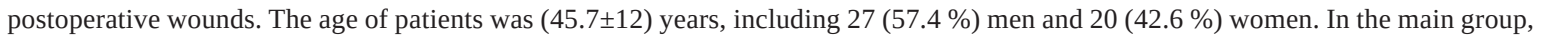
treatment was performed using a mobile pump for vacuum therapy of wounds NPWT KCI ActiVAC $300 \mathrm{ml}$. The comparison group used traditional gauze dressings with antiseptic solutions. All patients in both groups underwent antibacterial therapy, treatment of comorbidities. 
Results and Discussion. According to the results of the bacteriological analysis of wound exudate in patients of the main group on the third day, the microbial count decreased to $10^{5}-10^{6}$, in swabs of the wound necrotic type of cytograms changed to degenerativeinflammatory type in 19 (73.0 \%) patients and 7 (27.0) \%) of patients with inflammatory-regenerative type, while in the comparison group the indicators of microbial numbers remained at the previous level $10^{8}-10^{9}$ and in $15(71.4 \%)$ remained a necrotic type of cytograms and only 6 (28.6 \%) patients had degenerative-inflammatory type of cytograms. On the $10^{\text {th }}$ day in the main group in 24 (92.3\%) patients, there were the regenerative type of cytograms, in $2(7.7 \%)$ patients inflammatory-regenerative type. In the comparison group, 15 (71.5\%) had a degenerative-inflammatory type, 4 (19.0 \%) had an inflammatory-regenerative type of cytograms, and 2 (9.5 \%) had a necrotic type.

The implementation of negative pressure wound therapy for the treatment of infectious complications of postoperative wounds significantly improves the results of treatment and reduces the rehabilitation time for the patients.

Key words: negative pressure wound therapy; infectious complications; postoperative wound.

\title{
А. Ю. ИОФФЕ, С. Л. КИНДЗЕР, А. П. СТЕЦЕНКО, Т. М. ГАЛЫГА, А. В. ОМЕЛЬЧЕНКО
}

Национальный медицинский университет имени А. А. Богомольца, Киев

\section{ПРИМЕНЕНИЕ ВАКУУМНОЙ ТЕРАПИИ РАН В ЛЕЧЕНИИ ИНФЕКЦИОННЫХ ОС.ОЖНЕНИЙ СО СТОРОНЫ ПОС.ЛЕОПЕРАЦИОННЫХ РАН}

\begin{abstract}
Цель работы: улучшить результаты лечения больных с инфекционными осложнениями со стороны послеоперационных ран. Материалы и методы. В течение 2014-2019 лет в отделении гнойной хирургии Киевской городской больницы № 3 (база кафедры общей хирургии № 2 Национального медицинского университета имени А. А. Богомольца) получили лечение 47 больных с инфекционными осложнениями со стороны послеоперационных ран. Возраст пациентов составил $(45,7 \pm 1,2)$ лет, среди них $27(57,4 \%)$ мужчин и 20 (42,6\%) женщин. В исследуемой группе лечение осуществляли с использованием мобильной помпы для вакуумной терапии ран NPWT KCI ActiVAC $300 \mathrm{ml}$. В группе сравнения использовали традиционные марлевые повязки с растворами антисептиков. Всем больным в обеих группах проводилась антибактериальная терапия, лечение сопутствующей патологии.

Результаты исследований и их обсуждение. Согласно результатам бактериологического исследования раневого содержимого у больных исследуемой группы на третьи сутки микробное число снизилось до $10^{5}-10^{6}$, в мазках-отпечатках некротический тип цитограмм изменился на дегенеративно-воспалительный тип у 19 (73,0\%) больных и в 7 (27,0 \%) больных воспалительнорегенераторный тип, тогда как в группе сравнения показатели микробных чисел оставались на прежнем уровне $10^{8}-10^{9}$ и у 15 $(71,4$ \%) еще оставался некротический тип цитограмм и только у 6 (28,6 \%) больных отмечался дегенеративно-воспалительный тип цитограмм. На 10 сутки в исследовательской группе у 24 (92,3 \%) больных имел место регенераторный тип цитограмм, у 2 (7,7 \%) больных воспалительно-регенераторный тип. В сравнительной группе у 15 (71,5 \%) имел место дегенеративновоспалительный тип, в 4 (19,0 \%) воспалительно-регенераторный тип цитограмм, а в 2 (9,5 \%) больных некротический тип. Использование вакуумной терапии ран при инфекционных осложнениях послеоперационных ран значительно улучшает результаты лечения и сокращает сроки реабилитации больных.
\end{abstract}

Ключевые слова: вакуумная терапия ран; инфекционные осложнения; послеоперационная рана. 